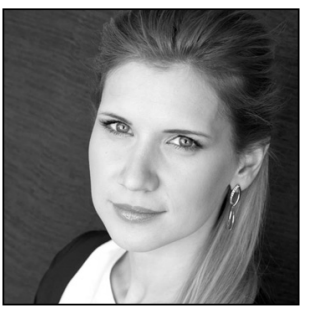

Katrin Sepp

Doctoral student

University of Tartu

\title{
Legal Arrangements Similar to Trusts in Estonia under the EU's Anti-money-laundering Directive
}

\section{Introduction}

To identify terrorists and money-launderers hiding behind legal entities or arrangements, EU Directive 2015/849 ${ }^{*_{1}}$ (4AMLD) introduced the 'UBO register'. In consequence, all Member States (MSs) have to establish a central register containing data on ultimate beneficial owners (UBOs) ${ }^{*_{2}}$ of corporate legal entities and also of trusts and legal arrangements similar to trusts (hereinafter 'SAs').

However, before 4AMLD was transposed into the national law of the various MSs, amendments to it referred to by the name ' 5 AMLD' and begun with the European Commission's 'Proposal for a Directive of the European Parliament and of the Council amending Directive (EU) 2015/849 on the prevention of the use of the financial system for the purposes of money laundering or terrorist financing and amending Directive 2009/101/EC of 5 July 2016' (referred to below as 'the Proposal') - were already on the table ${ }^{* 3}$. The final text of 5AMLD has not yet been agreed on, but it seems rather likely that it is going to usher in some serious changes pertaining to trusts and SAs. Inter alia, it probably will list such contractual devices as fiducie, Treuhand, and fideicomiso as examples of SAs ${ }^{*}$. The 4AMLD terms explicitly specified only foundations

1 Directive 2015/849 of the European Parliament and of the Council of 20 May 2015 on the prevention of the use of the financial system for the purposes of money laundering or terrorist financing, amending Regulation (EU) No 648/2012 of the European Parliament and of the Council, and repealing Directive 2005/60/EC of the European Parliament and of the Council and Commission Directive 2006/70/EC, 5.6.2015, L 141/73.

2 Generally, 'any natural person who exercises ownership or control over a legal entity' (Recital 12); more precise definitions are given in articles 30 (on corporations) and 31 (on trusts and SAs).

3 Available at http://www.europarl.europa.eu/RegData/docs_autres_institutions/commission_europeenne/com/2016/0450/ COM_COM(2016)0450_EN.pdf (most recently accessed on 27.6.2017). Since the release of the proposal, the Council of the EU has published several Presidency compromise texts amending and updating it. Additional parliamentary meetings and various counterproposals have contributed to the compromise texts. Several committees have reviewed the amendments - e.g., the European Economic and Social Committee (EESC) and the Economic and Monetary Affairs and Civil Liberties (EMACL) committees. After the vote by the EMACL group, the European Parliament gave the go-ahead, at the March plenary session, to start negotiations among said parliament, the Commission, and the Council on the details for the legislation. Voting in the European Parliament's plenary session is tentatively scheduled for October 2017. See http://www.europarl.europa.eu/ oeil/popups/ficheprocedure.do? reference=2016/0208(COD)\&l=en (most recently accessed on 27.4.2017).

4 See the Proposal (see Note 3)'s p. 16, proposed Recital 33 (p. 27), and proposed amendments to Article 31 (p. 33 ). 
as legal devices to which the same measures were to be applied as to trusts. ${ }^{*}$ Secondly, 5 AMLD is going to incorporate an attempt to determine in which MS the trusts and SAs should be registered - depending on where they are administered ${ }^{* 6}$ rather than which MS's law has been chosen to govern the trust or SA (the latter having been the approach of 4AMLD). This means also that the MSs must be able to recognise trusts and SAs established under and governed by the law of other countries (those not being limited to only MSs). Thirdly, the circle of persons to whom the data of UBOs will be available will most probably broaden. According to $4 A M L D$, the information concerning UBOs of trusts and SAs was already to be made directly accessible to competent authorities and financial intelligence units (FIUs) ${ }^{*}$. The initial proposal for 5AMLD suggested allowing public access to the data on those trusts and SAs that are 'business-type' and/or administered by professionals and granting it to those persons 'with legitimate interest' in the case of others. ${ }^{* 8}$ Since then, however, there have been proposals to disclose the UBO data of all trusts and SAs to the public. ${ }^{* 9}$

The MSs are expected to identify SAs used in their countries and to assure the submission of the data of related UBOs to a central database. ${ }^{{ }^{* 10}}$ It seems that, at the moment, Estonia has chosen to take the approach that, apart from foundations, there are no devices similar to trusts in our legal practice that should be subject to UBO-register rules. ${ }^{* 11}$ The aim with this article is to show that there are, in fact, arrangements in Estonian private law that have structure or functions similar to those of trusts and hence should be considered in the listing of SAs. In the paper, I also try to highlight the difficulties that arise in this regard. The article does not cover foundations, as these are instruments clearly addressed in both Estonian legislation and the AMLD ('AMLD' hereinafter referring to the 4AMLD and 5AMLD together as to the directive in general) text, for which reason no confusion as to whether they should be included in UBO registers should arise. For similar reasons, it does not cover corporate legal entities.

For determination of the SAs in Estonian legal practice, the concept of trust should be explained firstly. The 4AMLD and 5AMLD texts do not give a definition of trust. Instead, both equate it with instruments used in civil-law systems that have similar structure or functions. Therefore, in addition to providing an introduction to trusts, the first section below gives a brief overview of the two SA types mentioned in the preparatory documents for the 5AMLD - the Treuhand and fiducie - and proceeds to highlight the similarities between these and the trust, which should later aid in ascertaining the SAs in Estonian legislation. Next, the article turns to the Estonian legal scene and attempts to find arrangements that are similar to trusts. Under consideration are family- and succession-law devices (e.g., executorship of a will), various forms of shared ownership and communities (in particular, silent partnership and contractual investment funds), mandate and commission contracts, intermediated holding of securities, and fiduciary ownership for security purposes.

\section{Trusts and SAs under the directive}

\subsection{Trusts}

Purposes. The institution of the trust has developed mainly in jurisdictions based on the English legal system. For a long time, it has been viewed as unique to common law since civil-law countries do not have a device that is this flexible and universal for extending across so many legal relationships.

5 E.g., Recital 17.

$6 \quad$ Ibid., p. 18, proposed Recital 21 (p. 25), and proposed amendments to Article 31 (pp. 34-35).

7 MSs can decide whether access is to be provided also for obliged entities (Art. 31(4)). The persons with 'legitimate interest' are not mentioned in the case of trusts and SAs.

$8 \quad$ Ibid., p. 10, proposed Recital 35 (p. 28), and proposed amendments to Article 31 (pp. 33-34).

9 E.g., the Opinion of the Committee on Development (1.12.2016). Available at http://www.europarl.europa.eu/sides/getDoc. do?pubRef=-//EP//NONSGML+COMPARL+PE-594.116+02+DOC+PDF+V0//EN\&language=EN (most recently accessed on 29.4.2017).

10 See, for instance, the added para. 10a in the draft European Parliament legislative resolution. Available at http://www. europarl.europa.eu/sides/getDoc.do?type=REPORT\&mode=XML\&reference=A8-2017-0056\&language=EN\#_part1_def3 (most recently accessed on 29.4.2017).

11 See the draft legislation for implementing the 4AMLD (rahapesu ja terrorismi rahastamise tõkestamise eelnõu), available at https://www.riigikogu.ee/tegevus/eelnoud/eelnou/fb03e20e-caf7-463d-9b60-ddf6021742b2/Rahapesu\%20ja\%20 terrorismi\%20rahastamise\%20tõkestamise\%20seadus (most recently accessed on 28.6.2017). 
In common-law countries, trusts are used for a great variety of purposes: protection of (family) assets; administration and provision related to vulnerable persons, such as minors, addicts, and the disabled; preservation of an object or appropriation of property for a specific use ${ }^{*_{12}}$; investment (unit trusts / mutual funds) ${ }^{{ }^{*} 13}$; provision for employees upon their retirement (as with pension trusts) ${ }^{{ }^{*} 14}$; charity; management of the collateral in cases wherein there is a large number of creditors or when the same security is to benefit successive groups of creditors (syndicate loans, secured-bond issuance) ${ }^{*}{ }^{*}$; etc. Testamentary trusts are created by a person's will and arise upon the death of the testator.

While the above-mentioned trusts are express trusts - i.e., knowingly created by a person - there also exist trusts that are imposed by law or a court: constructive trusts, statutory trusts, and resulting trusts ${ }^{*} 16$. Statutory trusts arise under statutes stipulating that under certain circumstances the property shall be held in trust, as in the case of trusts arising in respect of legal estates that are co-owned or with intestacy. ${ }^{*}{ }^{17}$ Constructive trusts are imposed by courts as a remedy, e.g., to prevent unjust enrichment. ${ }^{*} 8$ Resulting trusts can be created (in the transferor's favour) in cases wherein property is gratuitously transferred and there is insufficient evidence to ascertain the transferor's intention - i.e. that the transferor meant to make a gift or loan and abandon his beneficial interest. ${ }^{* 19}$

Definition and parties. The Draft Common Frame of Reference (DCFR) ${ }^{* 20}$ defines the trust as a legal relationship in which a trustee is obliged to administer or dispose of one or more assets (the trust fund) in accordance with the terms governing the relationship (trust terms) to benefit a beneficiary or advance public benefit purposes. The person who constitutes the trust and defines the trust terms is called the settlor ${ }^{* 21}$. The roles of the parties may overlap. ${ }^{* 22} \mathrm{~A}$ trust is not a legal entity or a contract ${ }^{* 23}$.

Fiduciary ownership. An essential feature of a trust is that the title ${ }^{* 24}$ to the trust fund is vested in the trustee: 'For the purposes of performing the trust the trustee is cloaked in the mantle of an outright owner. ${ }^{* 2} 25$ But the interpretation of 'title' is not always synonymous with 'ownership'. In most trust jurisdictions, the trustee actually becomes the owner of the trust fund ${ }^{* 26}$. But some civil-law jurisdictions that have

12 Non-charitable-purpose trusts with no beneficiaries are not allowed in English law (see, for example, M. Lupoi. Trusts: $A$ Comparative Study. Cambridge University Press 2000, p. 123) but are possible in other jurisdictions.

13 D. Hayton et al. Underhill and Hayton Law of Trusts and Trustees. 18th ed. LexisNexis 2010, p. 67.

14 Ibid., p. 69.

15 Ibid., p. 60.

16 Ibid., p. 420.

17 Ibid., p. 420.

18 Ibid., p. 83.

19 Ibid., p. 81.

20 C. von Bar et al. (eds). Principles, Definitions and Model Rules of European Private Law: Draft Common Frame of Reference. Outline edition, 2009. Available at http://ec.europa.eu/justice/contract/files/european-private-law_en.pdf (most recently accessed on 29.4.2017). The trust of Book X of the DCFR is the latest example of international trust models - it takes the civil-law approach to an English trust and, accordingly, should be comprehensible also for lawyers of a civil-law jurisdiction. As it is the only trust model that has been agreed upon (to some extent) among the MSs and that could possibly serve as a model for domestic or European trust legislation in the future, the author of this article has chosen the provisions of Book $\mathrm{X}$ for giving an overview of the definition and main components of the trust.

21 In the DCFR, the term 'truster' is used.

22 However, under the DCFR, a person cannot be a sole trustee for solely that person's benefit (X.-9:109).

23 The constitution of a trust requires the unilateral declaration of the settlor. If it is not a self-declaration trust, wherein the settlor is also the sole trustee, the transfer of the assets from the settlor to the trustee is the second prerequisite. See p. 5680 in C. von Bar, E. Clive (eds). Principles, Definitions and Model Rules of European Private Law: Draft Common Frame of Reference (DCFR), Volume 6. Oxford University Press 2010.

24 Nevertheless, it might be that the trustee further invests the trust assets. In that case, 'a custodian, on behalf of a trustee (and on trust for the trustee qua trustee), has title to what laymen consider to be the trust assets although, strictly speaking, it is the trustee who has title to his rights against the custodian, such rights actually being the trust assets,' states D. Hayton. The trust in European commercial life. - J. Lowry, L. Mistelis (eds). Commercial Law: Perspectives and Practice. LexisNexis Butterworths 2006.

25 C. von Bar, E. Clive (see Note 23), p. 5691.

26 In legal literature, the trust-specific situation in common law countries, where the title of an asset is held by a person who administers it for the benefit of another, has often been illustrated through the 'split ownership' concept, in which the legal title belongs to the trustee and the beneficiary has the beneficial/equitable title. Nowadays, legal scholars writing on trusts are more of the opinion that the abovementioned 'title-split' does not exist, that it has been used to clarify the trust concept to civil law lawyers and that the trustee is really the full owner. See, e.g., P. Matthews. The compatibility of trust with the civil law notion of property. - L. Smith (ed.). The Worlds of the Trust, p. 316. Cambridge University Press 2013. - DOI: https:// doi.org/10.1017/CBO9781139505994.015. 
applied the trust use different solutions: in China, Louisiana, and Quebec, 'title' to trust property is in the name of the trustee whilst ownership of the trust property is said to lie with the settlor, beneficiary, or none of the trust parties, respectively. ${ }^{* 27}$

Even if the trustee is the owner, it must be remembered that the trust assets have only been passed to him for the purposes set forth in the trust terms. Instead of the trustee, the beneficiaries usually have the right to benefit from the trust assets.

The settlor or beneficiaries should not have the right to order the trustee around - the retaining of powers by the settlor must not extend past the limit beyond which the trust can be deemed void or 'sham,*28. However, some jurisdictions (mainly offshore) do allow trusts that would be considered 'sham' in others.

Segregation of patrimonies. With the trustee being the owner of the trust fund, he can be personally liable to satisfy trust debts (the first rule regarding creditors still is that they may satisfy their rights out of the trust fund) ${ }^{* 29}$, but his personal creditors shall not have recourse to the fund, as the trust fund is to be regarded as a patrimony distinct from the personal patrimony of the trustee and any other patrimonies vested in or managed by the trustee. ${ }^{*}{ }^{30}$ The trust fund is also immune from claims by the trustee's heirs and spouse. ${ }^{*}{ }^{31}$ Neither shall the trust fund be available for creditors of the settlor or beneficiary (although they may appeal to the beneficiary's rights related to the trust fund ${ }^{*}{ }^{32}$ ), nor are the beneficiary and the settlor in that capacity liable to a trust creditor. ${ }^{*} 3$

Tracing. Another specific feature of the common-law trust is the special nature of the rights of beneficiaries against third persons in the event of misappropriation of the trust assets by the trustee. Although beneficiaries are not the owners of trust assets, they might have a claim against a third-party recipient who is not an acquirer for value in good faith. ${ }^{*} 34$

\subsection{The similarity in SAs}

The Treuhand. In Germany ${ }^{*} 35$, the Treuhand is a contractual relationship wherein a person (the Treuhänder) is entrusted with certain property (the Treugut), which he has to administer or dispose of, not in his own interest but in the interest of another person (the Treugeber) or for a specific purpose.

This institution is not explicitly regulated by law and is instead governed by academic writings and case law. Usually, the provisions regulating a mandate or contract for the management of affairs of another are applied also. ${ }^{*} 36$

A distinction is made between the security Treuhand and the administrative Treuhand: the former protects the interests of the Treuhänder by providing him with security through the transfer of assets; in the case of the latter, the Treuhänder manages the assets in the interests of the Treugeber. ${ }^{*} 37$

The Treuhänder becomes the owner of the assets transferred to him and, as an owner, may dispose of them. The contract creating the Treuhand can set certain limits for that, but these have only obligatory effect. Hence, dispositions made in breach of such obligations are generally valid. ${ }^{*} 38$ In the event of misappropriation of property by the Treuhänder, the beneficiary could have an in personam claim against the third-party transferee if the Treuhänder himself is insolvent and also the transferee has conspired with the Treuhänder to damage the Treugeber or the beneficiary. ${ }^{*} 9$

\footnotetext{
D. Clarry. Fiduciary ownership and trusts in a comparative perspective. - International and Comparative Law Quarterly 63 (2014) / 4 (Oct.), pp. 901-933, on p. 926. - DOI: https://doi.org/10.1017/S0020589314000463.

28 See, for example, D. Hayton et al. (see Note 13), pp. 88-97.

29 X.-10:101(1), X.-10:201(1), and X.-10:202 of the DCFR.

30 X.-1:202(1)(2)(a) of the DCFR.

31 X.-1:202(2)(b)(c) of the DCFR.

32 X.-10:101(1) of the DCFR.

33 X.-10:203 of the DCFR.

34 See M. Lupoi (Note 12), pp. 58-65.

35 The Treuhand is used also in Austria, Switzerland, and Liechtenstein.

36 S. van Erp, B. Akkermans (eds). Cases, Materials and Text on Property Law. Hart Publishing 2012, p. 565.

37 D. Krimphove. National report for Germany. - S.C.J.J. Kortmann et al. (eds). Towards an EU Directive on Protected Funds, pp. 115-143. Kluwer Legal Publishers 2009, p. 117.

38 S. van Erp, B. Akkermans (Note 36), p. 583.

39 Ibid., p. 613.
} 
The Treugeber never quite drops out of the picture: the Treuhänder has an obligation to report to the Treugeber, and it is possible for the Treugeber to be allowed to revoke the Treuhand. While the Treuhänder is the owner, the Treugut is still 'economically' deemed to belong to the Treugeber. Therefore, in cases of insolvency of the Treugeber, the creditors of the Treugeber can reclaim the Treugut from the Treuhänder (but this is only a personal claim). ${ }^{*}{ }^{40}$ On the other hand, when the Treuhänder is insolvent, the Treugeber or third-party beneficiary can oppose attacks from personal creditors of the Treuhänder and demand release of assets belonging to the Treugut (but only if those assets have been provided to the Treugut directly from the Treugeber). ${ }^{*} 4$

The fiducie. Article 2011 of the French Civil Code ${ }^{*} 42$ defines the fiducie as a transaction with which the constituant ${ }^{*} 43$ transfers things, rights, or securities to the fiduciarie, who, keeping them segregated from his own patrimony, acts so as to further a particular purpose for the benefit of beneficiaries.

French law explicitly states that the fiduciary patrimony is subject to execution only for debts arising from the keeping or management of this patrimony ${ }^{*} 44$ and is thereby protected from the creditors of the fiduciarie $^{*} 45$ as well as of the constituant. Unlike under the law of England or Germany, only specific institutions or professions can function as a fiduciarie: individuals, apart from avocats, are excluded. ${ }^{*} 46$ It is used mainly as a security device (fiducie-sureté) ${ }^{*} 47$, wherein the fiduciarie is the beneficiary also, and for management purposes for the benefit of the constituant himself (fiducie-gestion). A fiducie cannot be set up for a third-party beneficiary (unless that beneficiary confers upon the constituant a benefit somehow equivalent to the value of the things he receives) ${ }^{*} 48$. In France, a fiducie has to be registered. ${ }^{*} 49$

The common feature. While in common law a trust is not a legal entity or a contract, the similar instruments mentioned in 5AMLD are of contractual nature, as with the Treuhand and fiducie, or are legal entities, such as foundations. Also, while with a trust the assets constituting the trust fund are ring-fenced, such that protection is included in the event of insolvency of the settlor, the Treuhand ends in consequence of insolvency of the Treugeber and the assets may then be reclaimed from the Treuhänder, so we can say that the segregation of property is not an obligatory feature for an arrangement to be treated as similar to trusts under the AMLD. The beneficiaries' rights against third persons in cases of misappropriation of property by the trustee are generally stronger in the case of trusts. ${ }^{*} 50$

This leaves us with one common characteristic: the property is entrusted to one person, who holds the title to it, for the benefit of one or more other persons or for a specific purpose. Hence, from the outside the property has one person as an owner, but there exists an internal relationship also - potentially invisible to the public - which obliges the trustee to observe certain duties and which may enable another person to gain the economic benefit from the trust property. Below, the further examination of the possible SAs in Estonia proceeds from this conclusion.

\section{Possible SAs in Estonia}

\subsection{Succession- and family-law devices}

Although there are legal structures that are functionally similar to trusts in that they cater for the same sorts of needs as are dealt with by the trust in common-law countries, in the AMLD context we can presumably exclude those with no 'hidden' beneficial owner.

$40 \quad$ Ibid., p. 614.

41 Ibid.

42 Code Civil, law no 2007-211 of 19 February 2007.

43 A legal or a natural person.

44 Article 2025(1) of the Code Civil.

45 Article 2024 of the Code Civil.

46 S. van Erp, B. Akkermans (Note 36), p. 577.

47 See, for example, F. Barrière. The security fiducie in French law. - L. Smith (ed.). The Worlds of the Trust, pp. 101-140. Cambridge University Press 2013. - DOI: https://doi.org/10.1017/CBO9781139505994.008.

48 S. van Erp, B. Akkermans (Note 36), pp. 576-575.

49 Articles 2010 and 2019 of the Code Civil.

50 S. van Erp, B. Akkermans (Note 36), p. 613. 
So, although a testator can appoint an executor of will ${ }^{*}{ }^{11}$ or a court can appoint an administrator for the estate of the deceased ${ }^{*}{ }^{2}$, who might have the right to possess, use, or dispose of the property (while the successor does not have the right to dispose of it), the successor - and not the executor or administrator - will be recorded as the owner of the property in the respective registers. Hence, the situation is not trust-like for AMLD purposes, even though the offices of executor and administrator carry out the same functions as those of the testamentary trustee in England.

The same applies to guardianship of vulnerable persons - although the guardian might have obligations similar to the trustee's, the person under guardianship is still regarded as the owner, although he does not have the right to enter into transactions himself ${ }^{*} 53$. Also, in this context, there is probably no need for a lengthy analysis of the institute of representation ${ }^{*} 54$, wherein one person can conduct transactions for another but does so not in his own name or on his own behalf but for the principal (although, again, some of his duties might be similar to duties of a trustee).

Also, the Law of Succession Act (LSA) provides for the possibility of naming a subsequent successor: in the case of arrival of a particular date or fulfilment of a set condition, the estate or a share thereof transfers from a provisional successor to a subsequent successor (see the LSA's §45(1)). The right of disposition of the provisional successor might be somewhat restricted (under the LSA, $\S \S 48$ and 54). This arrangement may resemble an interest-in-possession trust ${ }^{*} 55$, but until the relevant date or condition has come to pass (and the subsequent successor is to be transferred ownership), the subsequent successor, in that capacity, will have no 'hidden' beneficial rights with regard to the estate and the provisional successor is the full owner. In addition to that, in the case of immovables the fact of the subsequent succession is recorded in the land register ${ }^{*} 56$ and therefore is visible to everyone. Needless to say, the situation of subsequent succession can only arise in the case of someone's death, which makes it an ineffective means for money laundering.

\subsection{Shared ownership and communities}

As was mentioned earlier in the paper, in common-law countries trusts also can be established in cases wherein, for example, land is owned by more than one person. ${ }^{*} 7 \mathrm{In}$ Estonia, when a right or a thing belongs to several persons at the same time, this is usually manifested by the entry in the relevant register ${ }^{*} 58-$ if the object of shared ownership ${ }^{* 59}$ or community (ühisus ${ }^{*} 60$ ) has to be registered - or, in the case of movables, by the joint possession ${ }^{* 61}$. Hence, in cases of co-owners ${ }^{* 62}$, spouses $^{*} 63$, co-successors ${ }^{*}{ }^{*}$, and an 'ordinary' partnership (seltsing) ${ }^{*} 65$, there is no 'hiding' the owner and the situation cannot be deemed trust-like in that sense.

51 Under the terms of sections 78-87 of the Law of Succession Act (pärimisseadus). - RT I 2008, 7, 52; 10.3.2016, 16. English text available at https://www.riigiteataja.ee/en/eli/528032016001/consolide (most recently accessed on 29.4.2017).

52 See Section 112 of the LSA.

53 See Sections 8-12 of the General Part of the Civil Code Act, or tsiviilseadustiku üldosa seadus (GPCCA). - RT I 2002, 35, 216; 12.3.2015, 106. English text available at https://www.riigiteataja.ee/en/eli/528082015004/consolide (most recently accessed on 29.4.2017).

54 See Sections $115-131$ of the GPCCA.

55 In the case of an interest-in-possession trust, one beneficiary is granted a right to the income from the trust or the right to use it, by the settlor. Upon the death of said (first) beneficiary, the rest of the fund may pass to another beneficiary.

56 See $\S 49^{1}$ of the Land Register Act, or kinnistusraamatuseadus (LRA). - RT I 1993, 65, 922; 28.6.2016, 8. English text available at https://www.riigiteataja.ee/en/eli/515122016002/consolide (most recently accessed on 29.4.2017).

57 M. Lupoi (Note 12), p. 19.

58 See the LRA, §14(2). Also, §70 of the Law of Property Act, or asjaõigusseadus (LPA). - RT I 1993, 39, 590; 25.1.2017, 4. English text available at https://www.riigiteataja.ee/en/eli/526012017002/consolide (most recently accessed on 29.4.2017).

59 See the LPA, §70(1).

60 If a right belongs to several persons. See the LPA's §70(7).

61 See the LPA's §32ff.

62 Under $§ 70(3)$ of the LPA.

63 Under §25 of the Family Law Act (perekonnaseadus). - RT I 2009, 60, 395; 21.12.2016, 12. English text available at https:// www.riigiteataja.ee/en/eli/527122016004/consolide (most recently accessed on 29.4.2017).

64 See $\S 147$ of the LSA.

65 See §§ 596-609 of the Law of Obligations Act, or võlaõigusseadus (LOA). - RT I 2001, 81, 487; 31.12.2016, 7. English text available at https://www.riigiteataja.ee/en/eli/524012017002/consolide (most recently accessed on 29.4.2017). 
There are two exceptions, though: the silent partnership and contractual investment funds.

While in cases involving an 'ordinary' partnership, the parties to the partnership are visible from the outside, then in the case of silent partnership ( $\S \S 610-618$ of the Law of Obligations Act, modelled after the German Stille Gesellschaft) only one of the parties (the 'proprietor') is visible to third persons, while there exists an internal relationship that offers privacy to the other party to the contract - the silent partner. The silent partner makes a contribution (cash, services, or other assets) to the business of the proprietor and in return is entitled to share in the profits arising from the business. The contribution normally becomes the property of the proprietor. With respect to third parties, the proprietor is the owner of the commercial enterprise and carries on business in his own name. For certain operations, the proprietor should obtain the consent of the silent partner, but not having that consent does not affect the validity of the transactions concluded (the silent partner will have a personal claim against the proprietor). ${ }^{*} 66$ The silent partner is generally not liable for third-party claims arising from the business ${ }^{*} 67$. Nevertheless, if agreement is not made otherwise, he has to participate in the losses of the business ${ }^{*}{ }^{68}$. Under the partnership agreement, the silent partner might have the right to participate in the decision-making. ${ }^{*}{ }^{*} 9$ The partnership comes to an end when either of the parties goes bankrupt. ${ }^{*} 70$ The assets contributed to the enterprise by the silent partner are not ring-fenced: when the proprietor (either natural or legal person) has several enterprises to his name or there are personal creditors there is no segregation, and the silent partner (or the contribution) has no specific protection.

Although the silent partnership would not qualify as a trust in the 'classical' sense, it seems that it fits the SA category for AMLD purposes. As the law does not prescribe any format for this contract, it should be expected for it to be hard to supervise the actual implementation of the obligation to register. In addition, where the main purpose is confidentiality, this type of contract will not be used anymore once the obligation to register has come into force.

In the case of contractual investment funds (common funds), the money collected through the issue of units and other assets acquired via the investment of said money are owned jointly by the unit-holders, and the management company ('manco') shall conclude transactions with the assets of the fund for the account of all the unit-holders collectively but in its own name (see \$4(1) of the Investment Funds Act $(\mathrm{IFA})^{{ }^{*} 71}$ ). This means that the manco will be recorded in the registries as having title to the property of the fund. ${ }^{*} 72$

Common funds also provide trust-style segregation of patrimonies: claims of creditors of the manco cannot be satisfied out of such assets. ${ }^{*} 73$ The funds are immune also from claims by creditors of unit-holders $^{*} 74$.

Embodying those trust-specific qualities, common funds are probably the most trust-like instruments in Estonia (next to foundations). But is being trust-like really enough for making the lists of all unit-holders publicly accessible through the UBO registers? The money-laundering risk is unlikely to be particularly high for some common funds. This is especially true for those subject to extensive regulation and Financial Supervision Authority oversight. It is worth mentioning too that all pension funds - including mandatory pension funds, in the case of which the sum accrues as a percentage of lawful income - are established as common funds in Estonia.

Also, in the case of trusts and SAs, the AMLD draws no distinction with regard to whether the beneficial owners have any actual decision-making rights (in the case of many common funds in Estonia, the unit-holders do not). However, if an investment fund were established as a corporation instead of using the contractual common fund format (in Estonia, these can be established as, for example, a public limited company or a limited

66 P. Varul et al. Võlaõigusseadus II. Kommenteeritud väljaanne ['Law of Obligations II, Commented Edition']. Tallinn 2007, p. 713.

67 Ibid.; LOA, $§ 610(3)$.

68 LOA, §§ 614(1) and 618(2).

69 P. Varul et al. (see Note 66), p. 717.

70 LOA, §§ 596(1)7) and 618(1).

71 Investeerimisfondide seadus. - RT I, 31.12.2016, 3 (in Estonian).

72 In the case of immovables, a notation needs to be made in the land register, indicating the fund on whose behalf the immovable is acquired. See §23(1)(4) of the IFA. The assets may, alternatively, be registered in the name of the depositary, if there is corresponding consent of the manco; see §296(2).

73 IFA, §26(4)(6).

74 IFA, $§ 13(4)$. 
partnership), there would be a threshold for the registration of UBOs. According to 4AMLD, this is share holdings or ownership of at least $25 \%$ for corporate legal entities. ${ }^{*} 5$ Accordingly, many of the investment vehicles established as corporations could escape the UBO-registration requirement while common funds could not.

\subsection{Commission and undisclosed mandate}

By contract of commission, the agent undertakes to enter into a transaction in his own name yet on account of the principal - e.g., to buy or sell an object for the principal ${ }^{*} 76$. This arrangement is a subspecies of authorisation agreement. Via an authorisation agreement (hereinafter also 'the mandate'), the mandatary undertakes to provide services to the mandator pursuant to the agreement ${ }^{*} 77$. These services may include negotiating and entering into contracts with third parties.

The Law of Obligations Act (\$626(3)) provides that the claims and movables acquired by the agent/ mandatary shall not be subject to a claim by the mandatary's/agent's creditors. But this segregation of patrimonies does not apply to immovables or rights other than claims. ${ }^{*} 78$ There is no sufficient Treuhand-like case law or doctrine in Estonia. In principle, the Supreme Court has recognised the possibility of fiduciary ownership also in the case of immovables ${ }^{*} 79$ : it is possible to construct trust-like devices whereby the ownership is transferred to an acquirer whose rights as an owner are restricted in the contract - he might be obliged to exercise the owner's rights for the benefit of the transferor by, for example, letting him use the asset. However, there will be no protection of the beneficiary's rights in the event of the trustee's insolvency or misappropriation of the property - unless, of course, the beneficiary's right is somehow made visible in the land register. For instance, if the parties have agreed that the beneficiary has a future right to acquire an immovable, it would be possible to enter in the land register a notation on this, which would serve the principle of publicity and guarantee that any disposal of said immovable after the entry of the notation in the register shall be void if it violates the rights of the beneficiary ${ }^{*} 80$. Having such a notation in the public registry would presumably remove the 'trust-like' component in AMLD context, however, and thereby release contracts of this kind from the UBO-registry burden. On the other hand, in the absence of such a notation, the practical implementation of this construction seems quite risky and hence would be expected to be infrequently applied.

\subsection{Intermediated holding of securities}

Commission and mandate contracts are often used in trading on stock exchanges and in other regulated markets. For the intermediated holding of securities, the specific provisions of the Securities Market Act $(\mathrm{SMA})^{*} 81$ and Estonian Central Register of Securities Act (ECRSA) ${ }^{*} 82$ apply in addition to the Law of Obligations Act.

Intermediated holding of securities that are registered in the Estonian Central Register of Securities (ECRS), such as shares of public limited companies except investment funds, can be accomplished through a nominee account (ECRSA, §6). When exercising the rights and performing the obligations arising from the securities, the holder of the nominee account has to follow the instructions of the client. Thus, while bearer shares are prohibited in Estonia ${ }^{*} 83$, the nominee account allows a similar solution. However, the list

\footnotetext{
Compare Article 3(6)(b), Article 31(1), Article 3(6)(a), and Article 30 of 4AMLD.

LOA, §692(1).

LOA, $\S 619$.

78 P. Varul et al. Võlaõigusseadus III. Kommenteeritud väljaanne ['Law of Obligations III, Commented Edition']. Tallinn 2009, p. 22.

79 CCSCd 23.9.2005, 3-2-1-80-05, paragraph 22. - RT III 2005, 29, 300 (in Estonian).

80 LPA, §63(3)(5).

81 Väärtpaberituru seadus. - RT I 2001, 89, 532; 7.4.2017, 4. English text available at https://www.riigiteataja.ee/en/ eli/519042017001/consolide (most recently accessed on 29.4.2017).

82 Eesti väärtpaberite keskregistri seadus. - RT I 2000, 57, 373; 31.12.2016, 25. English text available at https://www.riigiteataja.ee/en/eli/518012017004/consolide (most recently accessed on 29.4.2017).

83 All shares have to be registered, and the rights attached to a registered share shall belong to the person who is entered as the shareholder in the share register - see §228 of the Commercial Code (Äriseadustik). - RT I 1995, 26, 355; 13.7.2016. Bearer shares were allowed until 2001.
} 
of possible holders of nominee accounts is limited. ${ }^{*} 4$ Also, a notation shall be made in the register indicating that the account is a nominee account (the identity of the client will not be disclosed).

With regard to the creditors of the holder of a nominee account, the securities are deemed to be those of the client and not the holder of the nominee account (see §6(4)(6) of the ECRSA). The same applies for other securities held in custody for clients (under §88(6) of the SMA).

\subsection{SAs for security purposes}

In addition to the purposes of management or mere holding of assets, fiduciary ownership for security purposes - assignment of rights or transfer of ownership of things in order to provide collateral - is used. ${ }^{*} 85$ Again, there are no express provisions regulating these relationships (the only exception being financial collateral ${ }^{* 86}$ ), and they are not recognisable as such to third parties.

Using a security agent for purposes of securing bond issuance and syndicate loans can feature a mix of the mandate and the assignment of rights or transfer of ownership of things to the security agent. To third persons, the security agent is the holder of a restricted real right (pledge or mortgage) or an object that has been transferred to him, but he has to exercise the associated rights in the interests of the investors/ lenders. ${ }^{*} 87$

Again, those arrangements used for security purposes are definitely trust- or Treuhand/fiducie-like, but are they really dangerous money-laundering-wise and in need of being registered? ${ }^{*} 88$

\section{Conclusions}

Section 2 showed that the SAs mentioned in the preparatory texts for the 5AMLD - the Treuhand and the fiducie - do not share all the elements of a common-law trust. Accordingly, the conclusion was stated that in the AMLD context being 'trust-like' rather boils down to situations wherein from the outside the property has one person as an owner but there also exists an internal relationship that obliges the title-holder to observe certain duties and that may enable another person with the economic benefit from the property.

Section 3 showed that there indeed are arrangements in the Estonian legal system that fall into this category of SAs under the AMLD. Moreover, there are arrangements that embody more than one characteristic of the trust. This is, of course, not unexpected. Even though there is no single institution under Estonian law that could perform all the functions of a common-law trust, the same legal relationships exist. That said, just as not all trusts contain comfortably hidden and untaxed piles of valuable property, not all SAs of civil-law countries are ill-intentioned - many may well, for example, only hold an item with a very small value for a very short time as an object. It is hard to believe that the drafters of the AMLD really meant that all instruments that resemble a trust should be entered in UBO registries, but the definition related to being 'similar to trusts' is pretty vague. If one really wants, some similarity with trusts can be seen in many other structures wherein the right to benefit from an asset is not clearly manifested, but it would be an

84 Presumably, they are obliged entities with the obligation to identify their clients and perform other, respective tasks. See $\S 6(1)$ of the ECRSA.

85 P. Varul et al. Asjaõigusseadus II. Kommenteeritud vln. ['Property Law II, Commented Ed.']. Juura 2014, p. 434; K. Toommägi. Vallasasjade tagatisomandamine - selle olemus ja realiseerimine ['Security ownership transfers of movable assets essence and enforcement']. MA thesis. Tallinn 2014. Available at http://dspace.ut.ee/bitstream/handle/10062/43015/ toommagi_ma_2014.pdf?sequence=1\&isAllowed $=y$ (most recently accessed on 29.4.2017).

86 Financial collateral is the transfer of a right of claim to money in an account, securities, or a credit claim in order to provide collateral when both the collateral-provider and the collateral-taker are professional securities-market participants or when at least one party is in the latter class and the other one is a large corporation. See the LPA's $\S 314^{1} f f$.

87 See E. Pisuke. Võlakirjaemissiooni tagatisagent ['The role of the security agent in the issuance of bonds']. MA thesis, 2013. Available at http://dspace.ut.ee/bitstream/handle/10062/32187/pisuke_erki.pdf (most recently accessed on 29.4.2017); A. Kotsjuba. Tagatisagendiga kaasnevate riskide maandamine Eesti õiguses ['Mitigation of legal risks related to security agents under Estonian law']. MA thesis. Tallinn 2013. Available at https://dspace.ut.ee/bitstream/handle/10062/30849/ kotsjuba_andreas.pdf?sequence=1\&isAllowed=y (most recently accessed on 29.4.2017).

88 Firstly, on account of the nature of these relationships. Secondly, the beneficiaries might be quite easily identifiable in some cases, with one example being bondholders, who are registered in the ECRS in the case of securing bond issuance with the aid of a security agent. Then again, UBO registration in a special database is required also in cases involving corporations, whose owners are likewise identifiable via registers in Estonia. 
incredible burden to start registering them all and later supervise the fulfilment of the obligation of registration. Even the registration of just the SAs considered in Section 3 would cause a disproportionate administrative hassle, costs, and loss of privacy for decent citizens, while the actual money-launderers would in the future refrain from concluding contracts deemed trust-like and find other means (e.g., using 'straw men'). Therefore, I would say that the AMLD rules require clarification based on more careful study of the concept of trust or of arrangements that are used by money-launderers. Otherwise, we will see another example of 'costly failure' and 'ill-guided activism responding to the need "to be seen to be doing something" that anti-money-laundering policies have been accused of ${ }^{*} 89$.

As was mentioned in the introduction, Estonia seems to have chosen to take the stance that (apart from foundations) there are no SAs in our legal practice that are subject to UBO-register rules. I would dare to recommend an approach that is between the two extremes: to analyse the SAs by evaluating the risk of money laundering on the basis of aspects such as the parties involved, the arrangement's object, its value and the duration of the agreement, the costs of registering the UBOs, the proportionality of the infringement of the right to privacy of decent citizens, etc. and to work out the criteria for registration of SAs accordingly. 